\title{
Hemostatic devices in abdominal surgery
}

\author{
F Di Capua, M Petrocelli*, M M Saracco, A Vernillo, A Renda \\ From XXIII Annual Meeting of the Italian Society of Geriatric Surgery \\ Lecce, Italy. 2-4 December 2010
}

\section{Background}

Bleeding control is an important aim in surgery. A lot of haemostatic devices can be used to support hemostasis, so operative risks and length and hospital stay are reduced.

At General and Transplants Surgery Department of "Federico II" University of Naples, we evaluated the efficacy of hemostatic devices such as fibrin glues and collagen sponges in several surgical applications: kidney, gastroenteral, liver and pancreatic surgery.

Our aim is to find a specific use of each of the devices we used and to identify guidelines.

\section{Materials and methods}

From January 2010 and November 2010, we selected 30 patients older than 70 undergoing major surgery (16 cholectomies, 4 gastrectomies, 4 liver resections, 4 nephrectomies, 2 pancreatic resections); during surgery we used biomaterials.

We examined: amount and nature of abdominal drains, haemocromo and ultrasound control of possible presence of intra-abdominal collections.

We made a retrospective analysis of 30 age-matched patients undergoing surgery from 2000 to 2005, without the use of hemostatic agents.

\section{Results}

We found a shorter operating time and a lower incidence of postoperative complications such as bleeding, lymphocele, biliomi and pancreatic fistulas, of about $15 \%$. In addition, the incidence of complications due to the device itself was low: only one seroma and one case of granulomatous and fibrotic reaction.

* Correspondence: m.petrocelli@hotmail.it

Department of Surgical and Anestesiological and Reanimative Sciences, University of Federico II, Naples, Italy

\section{Discussion}

The experience of several authors in literature highlights the benefits of biomaterials haemostasis. The results of our experience are in line with those assessments.

\section{Conclusions}

Although you cannot disregard a careful surgical technique and classic methods, larger series and a longer follow-up are needed, the use of hemostatic aids have reduced the operative time and postoperative hospital stay presenting negligible complications and can therefore be considered a valid support.

Published: 24 August 2011

References

1. Takács I, Wegmann J, Horváth S, Ferencz A, Ferencz S, Jávor S, Odermatt E, Rõth E, Weber G: Efficacy of Different Hemostatic Devices for Severe Liver Bleeding: A Randomized Controlled Animal Study. Surg Innov 2010, 17(4):346-52.

2. Strada P, D'Angiolino A, Caloprisco G: Prelievo, preparazione, conservazione e assegnazione di componenti del sangue umano per uso terapeutico non trasfusionale. / Servizio Trasfusionale 2000, 6:I-XII.

doi:10.1186/1471-2318-11-S1-A10

Cite this article as: Di Capua et al.: Hemostatic devices in abdominal surgery. BMC Geriatrics 2011 11(Suppl 1):A10.

Submit your next manuscript to BioMed Central and take full advantage of:

- Convenient online submission

- Thorough peer review

- No space constraints or color figure charges

- Immediate publication on acceptance

- Inclusion in PubMed, CAS, Scopus and Google Scholar

- Research which is freely available for redistribution 